\title{
Statistical Analysis of the Physicochemical Characteristics of Urban Wastewater Treatment Plants from Romania
}

\author{
CARMELIA MARIANA DRAGOMIR BALANICA, CRISTIAN MUNTENITA*, \\ DANIELA ECATERINA ZECA, MARICICA STOICA
}

Dunarea de Jos University of Galati, 47 Domneasca Str., 800008, Galati, Romania

\begin{abstract}
The analysis of several criteria for influent and effluent of urban sewer water treatment plant in south and south east of Romania, has a crucial role in establishing the correlations between these factors, and furthermore to assess the efficiency of the treatment system. Increasing urbanization degree and its complexity has made studies of the pollution impact appraisal to be a necessity. The mean values of the parameters measured from the wastewater plant influent like temperature, $\mathrm{pH}$, suspended solids, chemical oxygen demand and biological oxygen demand vary from $17.13 \pm 0.23^{\circ} \mathrm{C}, 7.68 \pm 0.04,234.72$ $\pm 1.55 \mathrm{mg} / \mathrm{L}, 396.42 \pm 0.76 \mathrm{mg} / \mathrm{L}$, and $190.29 \pm 15.23 \mathrm{mg} / \mathrm{L}$, respectively. The values of the abovementioned quality indicators after the water treatment are $17.11 \pm 0.14^{\circ} \mathrm{C}, 7.56 \pm 0.03,22.6 \pm 1.02$ $\mathrm{mg} / \mathrm{L}, 62.95 \pm 0.16 \mathrm{mg} / \mathrm{L}$ and $20.49 \pm 9.06 \mathrm{mg} / \mathrm{L}$. Correlation study intended to define the feasible dependence among the evaluated parameters indicated that there were positive and negative correlations between the influent and effluent. The study conclusions point out the certitude that exist major optimizations in wastewater property after treatment processing.
\end{abstract}

Keywords: urban sewage treatment systems, pearson and spearman correlation

\section{Introduction}

Water management represents a significant challenge in numerous densely populated regions and countries all over the world. Considering the Water Framework Directive (WFD) protection of water resources, in Europe, is of primary importance at present and in the next periods. The main purpose of the WFD is to have adequate water quality in all continental waters by monitoring water bodies, i.e., not later by 2027 [1]. Moreover, as stated in the WFD, the ecological condition of surface waters is established on the basis of an integrated assessment method including hydro-morphological, chemical, physicochemical and biological factors and every quality parameter provides a distinct data on the state of aquatic ecosystems [2].

Worldwide demographic trends in addition to recent rigorous legislation for wastewater treatment plants (WWTPs) are today determining factors in order to improve and establish the newest treatment biotechnology, and also upgrading of existing ones. Although, increasingly advanced improvements in treatment have caused higher potential deterioration, increased electrical power usage, and higher environmental discharges [3]. In its entirety, these elements cause increasingly environmental challenges. Moreover, various WWTPs options have different efficacy at distinct treatment standards and therefore differing direct impacts on the environment. For these reasons, there is a requirement for comprehensive environmental evaluations within wastewater treatment facilities to accomplish specific treatment requirements in regard to environmental effects [4].

Wastewater treatment equipment have been developed to reduce the ecological effects of removing unprocessed sewage water. Several techniques of waste-water treatment have dissimilar efficiency particularities and likewise various immediate consequences on the aquatic system. Numerous wastewater treatment plants have major energy consumption, several systems occupy large areas [5,6]. The purpose of wastewater treatment is to generate the treated effluent but excluding the causing of damage or disturbance to the populations and avoiding water contamination. Mostly, urban wastewater consists in residual water from housing, industry and administrative institutions.

\footnotetext{
*email:cristian.muntenita@ugal.ro
} 
It contains a certain quantity of soluble or insoluble substances, and in most cases contains organic and inorganic elements. Furthermore, domestic wastewater may include micro-organisms (bacteria, protozoa, viruses, and helminths) [7]. Untreated urban wastewater discharge into rivers or lakes causes considerable algae growth, determines eutrophication and in lower layers when the dissolved oxygen is exhausted, fishes and other organisms that depend upon oxygen for outliving die $[8,9]$.

Sewage water treatment plants are projected to minimize the contamination in waste-water caused as a consequence of anthropogenic activities, but also to reduce its harmful impact on health of citizen [10]. Treatment of wastewater requires physico-chemical and frequently biological techniques. A major aspect in monitoring the water bodies impurity is to have precise data concerning the deleterious substances category and quantities in wastewater [11].

In the specialized literature exist distinct papers that examine the influent and effluent features in order to analyse the efficiency assessments of wastewater purification systems in several areas like Mumbai, India [12], Yola, Nigeria [13], Alice, South Africa [14], Haridwar, India [15], Paralimni and Agia Napa, Cyprus [16], Leon Province, Spain [17] and Tunceli, Turkey [18].

In Romania, ground water and surface waters, principally Danube river, represent the major source of raw water for drinking water production. The production of drinking water is a significant issue of developing countries. Surface waters content (natural organic matter, turbidity, $p \mathrm{H}$ ) relies on season and geographic area.

This article is the first study to determine several operational parameters, in south and south east of Romania, from urban sewage water treatment system and to calculate the correlation between the influent and effluent factors, furthermore to assess the treatment efficiency of equipment. Temperature, $p \mathrm{H}, \mathrm{SS}, \mathrm{COD}$ and $\mathrm{BOD}$ are thephysicochemical indicators investigated in this paper.

oxygen influences, nearly all chemical and biological processes within water bodies. Besides the $p \mathrm{H}$ is a fundamental variable in water quality assessment as it impacts multiple biological and chemical processes within a water body

\section{Materials and methods}

The municipal wastewater data provides from five counties from South and South Est of Romania: Giurgiu, Călărași, Brăila, Galați and Tulcea (Figure 1). The five wastewater treatment plants are located in the riverside municipalities of the Danube River and were built between 2011 and 2013. The studied area is a predominantly agricultural one and it covers around $26346 \mathrm{~km}^{2}$.

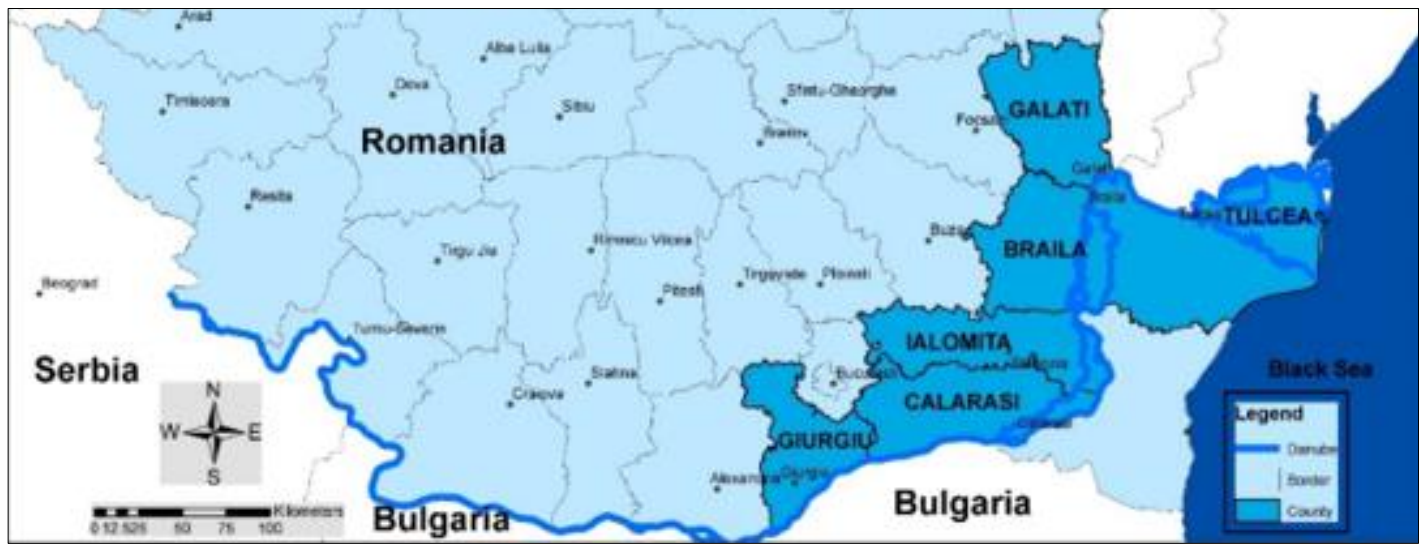

Figure 1. Urban wastewater treatment plants located in Romania

The wastewater treatment plants include physical mechanic treatment, biological treatment and a sludge dewatering station. Wastewater treatment plants are designed in accordance with the relevant effluent Standards regarding EU Directive 91/271 / EEC. The imposed indicators comply with European requirements, as follows: temperature $<35{ }^{\circ} \mathrm{C}, \mathrm{pH}$ from 6.5 to 8.5, Suspended solids (SS) $<35 \mathrm{mg} / \mathrm{L}$, chemical oxygen demand (COD) $<125 \mathrm{mg} / \mathrm{L}$ and biological oxygen demand (BOD) $<25 \mathrm{mg} / \mathrm{L}$. 
Wastewater firstly passes through rare grills and thick grills, each of them having three lines and a spare line with grill with manual bars and three impurities washing presses, lines of aerated separators provided with grease separators with two wash sorters and fat concentrators and distribution chamber, operating at the same time as a preanoxic basin (selector). The biological treatment step includes aeration basins in separate lines, equipped with a bubble aeration system, final sedimentation basins, recirculating active sludge pumping station, as well as excess active sludge, afterwards amalgamated with (re)activated sludge, and it is mixed with biological phosphorus unit under anaerobic conditions. Wastewater that are ushered in the distribution system is transferred excess active sludge storage basins and thickened sludge storage basins and then in the mechanical dewatering sludge plant with the centrifuge and the dewatered sludge cake storage area. The purified fluid is discharged into Danube River.

Water biochemistry is essential whereas several water parameters are purified and then are discharged to Danube river basin are determined through different analysis. Natural water may contain several pollutants substances or components in water treatment processes. The quantities and accumulations of different substances in water are generally reduced but fluctuate significantly.

The physical and chemical concentrations of the influents and effluents of wastewater treatment plants in Romania were assessed between January 2013 and December 2018, in order to observe their consequences on the receiving ecosystem. Experimental techniques used were standardized ones, particularly: water Temperature and $\mathrm{pH}$ measurements were done potentiometric utilizing a $\mathrm{pH}$ meter portable type INOLAB Multi 9620 IDS. BOD dataset was conducted with BOD Sensor System 6. COD was conducted with photocolorimeter HI 83314. SS were measured with standard methods with vacuum pumps.

Correlations among the indicators were calculated with SPSS 26.0 software (applying Pearson and Spearman correlation coefficients). Independent sample t-test analyze the variation in the means from the two groups to a certain data and it was applied to establish the statistical variance among influent and effluent measurements. For both influent and effluent, the yearly average of temperature, $p \mathrm{H}, \mathrm{SS}$, COD and BOD for the five cities were used as inputs in correlation analysis. The variations were supposed significant at $\mathrm{p}<0.05$ and $\mathrm{p}<0.01$ levels. The study present results as mean \pm standard deviation.

\section{Results and discussions}

Physicochemical indicators in particular temperature, $p \mathrm{H}, \mathrm{SS}, \mathrm{COD}$ and BOD have been stated to impact biological and chemical reactions inside the water bodies. Major modifications in the concentration of analysed indicators are denoting in alterations the quality of the water, having a negative impact on the public health.

Wastewater six years average data, collected from the plant influent and effluent to calculate different parameters and the results are presented in Figure 2.

The physical features of wastewater consist in colour, odour, temperature, and stream. The temperature of sewage water is ordinarily superior comparing of the water provide due to the extra warming water from urban residences and industrial sectors, but considerable quantities of storm drain effluent can provoke significant temperature variations. The temperature of the discharged water may impact downstream environments. Temperature may additionally influence the capacity of water to retain oxygen besides the capacity of organisms to withstand to several contaminants. Measurements used in the paper indicated that influent temperatures ranged between 8.7 and $24.7^{\circ} \mathrm{C}$ (mean $=17.13 \pm$ $0.21^{\circ} \mathrm{C}$ ) and treated effluent temperatures varied between 8.25 and $26.3^{\circ} \mathrm{C}$ (mean $=17.11 \pm 0.22^{\circ} \mathrm{C}$ ). $17.55^{\circ} \mathrm{C}$ the mean valued from 2016 is the highest average comparing to $16.84^{\circ} \mathrm{C}$ the lowest value from 2015. As stated by Council Directive 91/271/EEC concerning urban waste-water treatment, dasets of temperature were inferior to the water unloading standard $\left(35^{\circ} \mathrm{C}\right)[19]$. 


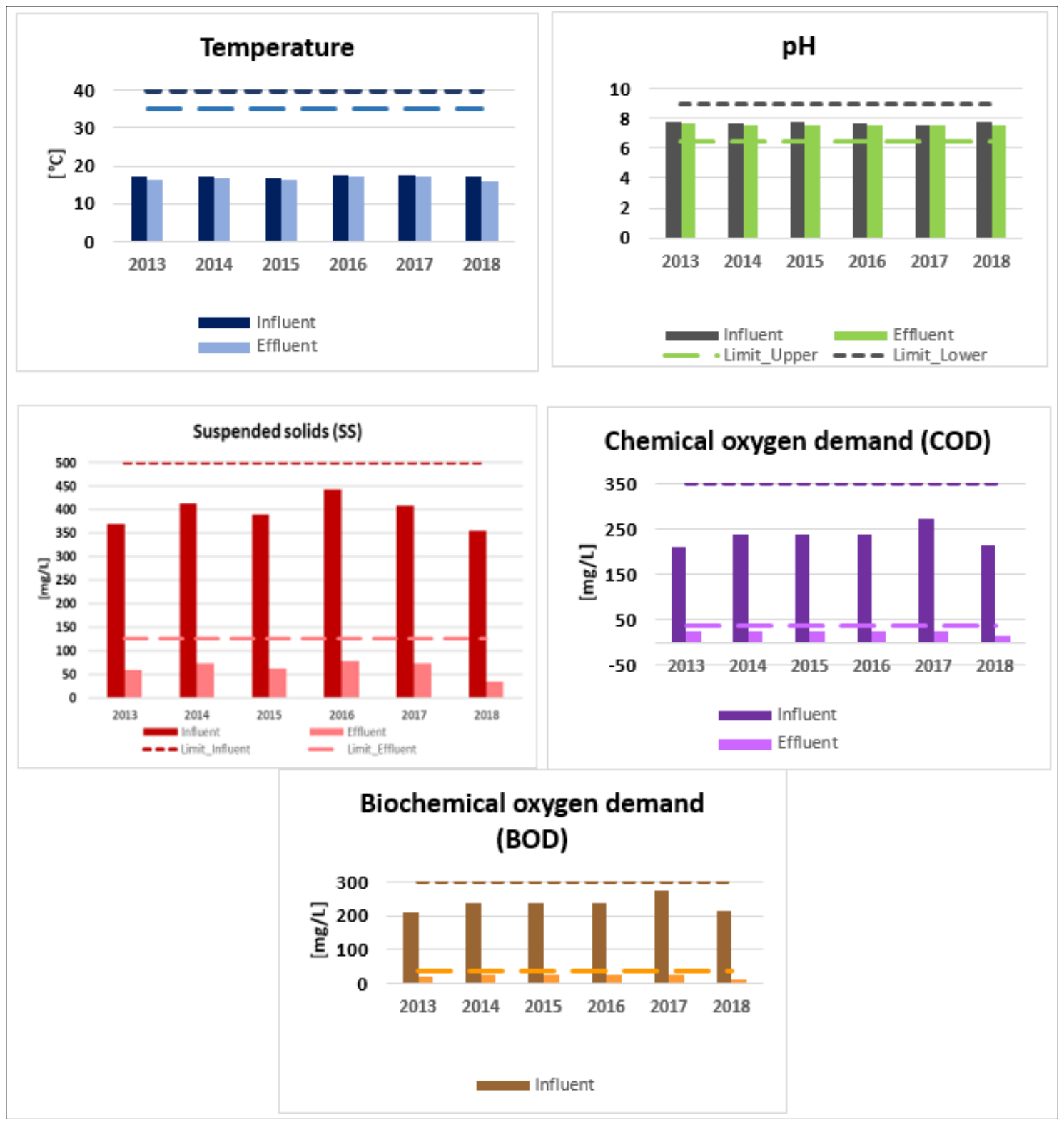

Figure 2. Yearly averaged data for influent and effluent of temperature, $p \mathrm{H}, \mathrm{SS}, \mathrm{COD}$ and BOD measured from 2013 to 2018

Natural water fluctuates in $p H$ relying upon its spring. Fresh water has a neutral $p \mathrm{H}$, having equal $\mathrm{H}+$ and $\mathrm{OH}-$. In order to monitor the chemical conditions, the water must be tested for the hydrogen ion concentration. The $p \mathrm{H}$ can influence the reserve of nutrients, biological processes, microbial impact, and the dispersion of pollutants. A $p \mathrm{H}$ too inferior or superior may be damaging for fish and aquatic system.

Pollution may modify the $p \mathrm{H}$ of water, which instead may affect organism and vegetables existence in the water. Organic matter or compounds include the element carbon resulting from flora and fauna. Organic items consist in oils, colorants, detergents, plastics, timber, combustibles, and papers. Organic compounds in aquatic system are generally substantial and do not decompose properly in water. $p \mathrm{H}$ value has principal weight in determining the quality for wastewater effluent. Wastewater $p \mathrm{H}$ varied between 7.15 and 8.09 before the treatment (mean $=7.68 \pm 0.03$ ) and between 6.56 and 8.05 (mean = $7.56 \pm 0.04$ ) after the wastewater purification. The dataset of measurements indicated that both influent and effluent wastewaters were insignificantly alkaline. The effluent $p \mathrm{H}$ values were between the accepted scale $(7.0 \div 8.5)$ by international legislation and regulations for potable and irrigation water 
$(6.5 \div 8.5)$ [18]. According to European legislation the protection threshold for pisciculture and aquatic system $p \mathrm{H}$ has 6.0 as lower limit and 9.0 as higher limit [20].

The clarity of water is an important feature. Turbidity in water is attributable to the existence of suspended matter, that results in the diffusion and concentration of luminous flux. As there is a larger quantity of suspended solids in the fluid, more impenetrable will be with a higher turbidity. Wastewater contains numerous distinct compounds that may be applied to describe it. The particular elements and quantities of individual will differ, relying on the spring. Wastewater assessment is frequently based on an average of industrial and domestic wastewater. Wastewater is defined regarding its physical, chemical, and biological properties. Suspended solids indicate the quantity of particles that exist in the wastewater. Most of suspended solids consist of inorganic materials, though bacteria and algae can also influence the total solids concentration. Whilst the influent suspended solids values ranged between $135.13 \mathrm{mg} / \mathrm{L}$ and $544.48 \mathrm{mg} / \mathrm{L}$ (mean $=234.72 \pm 15.98 \mathrm{mg} / \mathrm{L}$ ), effluent suspended solids values varied between $3.8 \mathrm{mg} / \mathrm{L}$ and $34.30 \mathrm{mg} / \mathrm{L}$ (mean $=22.76 \pm 3.35 \mathrm{mg} / \mathrm{L}$ ). 2016 is the year with highest average of influent $443,18 \mathrm{mg} / \mathrm{L}$ comparing to $77.31 \mathrm{mg} / \mathrm{L}$ the average of effluent. Throughout the studied period can be clearly observed the largest difference between the influent and the effluent.

The chemical characteristics of wastewater typically refer to like organic substance, the quantification of natural content, mineral component, and gases. On the other side these characteristics may be defined with reference to alkalinity, $\mathrm{BOD}, \mathrm{COD}$, nitrogen components, $p \mathrm{H}$, phosphorus, solids and fluid. $C O D$ is a assess of the quantity of oxidizable substance existing in the water. The COD is commonly in the limit of 200 and $500 \mathrm{mg} / \mathrm{L}$. The existence of industrial wastes may influence it substantially. $B O D$ is a value of the quantity of biologically degradable compound in the sewage water. This is ordinally determined by a five-day test performed at $20^{\circ} \mathrm{C}$. The BOD is usually in the limit of 100 up to $300 \mathrm{mg} / \mathrm{L}$. One of the major priorities of sewage water treatment systems is to decrease COD and BOD existing in the outflowing that may be evacuated in natural water basins. COD indicate the total oxygen quantity necessary for oxidation of whole biological substances in $\mathrm{CO}_{2} \mathrm{or}_{2} \mathrm{O}$. If large BOD flow is evacuated in an aquatic system, bacteria increase in the watercourse would hasten and besides the oxygen amount will reduce and mostly this effect is disastrous for aquatic biodiversity. COD and BOD limits for the waste water system influent fluctuated between 250 and $487 \mathrm{mg} / \mathrm{L}$ (mean = $396.42 \pm 37.98 \mathrm{mg} / \mathrm{L}$ ) respectively 56.88 and $304.14 \mathrm{mg} / \mathrm{L}$ (mean $=190.29 \pm 18.10 \mathrm{mg} / \mathrm{L}$ ), and for the treated effluent range between $12.69-168.87$ (mean $=62.67 \pm 8.59=$ ) for COD comparing to $5.5-76.90$ $\mathrm{mg} / \mathrm{L}$ (mean $=20.49 \pm 4.7$ ) for BOD. It should be noted that limits for wastewater discharge into waters is $125 \mathrm{mg} / \mathrm{L}$ for COD and $25 \mathrm{mg} / \mathrm{L}$ for BOD. The yearly average of influent and effluent COD highlights the largest difference among the characteristics of wastewater before to treatment and after that, e.g. in 2017 the influent average was $271.95 \mathrm{mg} / \mathrm{L}$ whereas the effluent was $23.66 \mathrm{mg} / \mathrm{L}$. Similar is the BOD with $229,05 \mathrm{mg} / \mathrm{L}$ the mean of influent and $21.82 \mathrm{mg} / \mathrm{L}$ the mean of effluent.

Overall, the efficiency of the wastewater treatment process results from the very large variations between the water quality before and after the treatment. SS, COD and BOD are the parameters that the difference between influent and effluent can reach up to ten times. Appling the standard removal efficiency method for SS we found the percentage varies from $88.93 \%$ until $93.32 \%, 81.98 \%$ and $90.47 \%$ are the lowest and highest percentage of removal efficiency for COD, while for BOD these values range from $86.81 \%$ to $93.23 \%$.

Pearson and Spearman Correlations analysis among the inflow and outflow indicators were studied and the values are indicated in Tables 1 plus 2. Although statistical calculations indicated a medium positive correlation amongst temperature and $p \mathrm{H}$ in the influent $(\mathrm{r}=0.447)$, between temperature and BOD in the influent $(\mathrm{r}=0.450)$ and it was calculated a medium significant positive correlation among $p \mathrm{H}$ and SS $(\mathrm{r}=0.479)$. The highest correlation it was between COD and SS $(\mathrm{r}=0.808)$, likewise importance being the correlation among COD and BOD $(\mathrm{r}=0.753)$. $(\mathrm{r}=0.627)$ is also a high the correlation between BOD and SS. A weak correlation is the one among $p \mathrm{H}$ and $\mathrm{BOD}(\mathrm{r}=0.143)$. 
Tables 1. Pearson Correlations and Spearman analysis among the influent parameters

\begin{tabular}{|c|c|c|c|c|c|c|}
\hline \multicolumn{2}{|c|}{ Correlation } & Temperature_ & pH_ & $\mathbf{S S}_{-}$ & COD_ & BOD_ \\
\hline \multirow[t]{5}{*}{ Pearson } & Temperature infl. & 1.000 & & & & \\
\hline & $\mathrm{pH}$ infl. & $.447 * *$ & 1.000 & & & \\
\hline & SS_infl. & $.437 * *$ & $.479 * *$ & 1,000 & & \\
\hline & COD_infl. & $.423 * *$ & $.362 *$ & $.808 * *$ & 1.000 & \\
\hline & BOD_infl. & $.450 * *$ & .0143 & $.627 * *$ & $.753 * *$ & 1.000 \\
\hline \multirow[t]{5}{*}{ Spearman } & Temperature_infl. & 1,000 & & & & \\
\hline & pH_infl. & $.540 * *$ & 1.000 & & & \\
\hline & SS_infl. & $.436^{*}$ & $.440^{*}$ & 1,000 & & \\
\hline & COD_infl. & .293 & .261 & $.608 * *$ & 1.000 & \\
\hline & BOD_infl. & .292 & -.057 & .344 & $.728 * *$ & 1.000 \\
\hline \multicolumn{7}{|c|}{ tion is significant at the 0.01 level (2-tailed). } \\
\hline \multicolumn{7}{|c|}{ *. Correlation is significant at the 0.05 level (2-tailed). } \\
\hline
\end{tabular}

Spearman's correlation indicates a strong positive correlation between COD and BOD $(r=0.728, p$ $<0.05)$ and between COD and Suspended solids $(\mathrm{r}=0.608, \mathrm{p}<0.05)$. An important correlation is the one between Temperature and $p \mathrm{H}(\mathrm{r}=0.540, \mathrm{p}<0.05)$. Moderate positive correlation was between SS and Temperature $(\mathrm{r}=0.436, \mathrm{p}<0.05)$ and between $\mathrm{SS}$ and $p \mathrm{H}(\mathrm{r}=0.440, \mathrm{p}<0.05)$. A weak negative correlation was among $p \mathrm{H}$ and $\mathrm{BOD}(\mathrm{r}=-0.057, \mathrm{p}<0.05)$.

Tables 2. Pearson and Spearman Correlations analysis among the effluent parameters

\begin{tabular}{|c|c|c|c|c|c|c|}
\hline \multicolumn{2}{|c|}{ Correlation } & Temperature_ & pH_ & $\mathbf{S S}_{-}$ & COD_ & BOD_ \\
\hline \multirow[t]{5}{*}{ Pearson } & Temperature_effl. & 1.000 & & & & \\
\hline & pH_effl. & $.455 * *$ & 1.000 & & & \\
\hline & SS_effl. & -.178 & .136 & 1.000 & & \\
\hline & COD_effl. & .086 & $.454 * *$ & $.822 * *$ & 1.000 & \\
\hline & BOD_effl. & .016 & $.460 * *$ & $.898 * *$ & $.551^{* *}$ & 1.000 \\
\hline \multirow[t]{5}{*}{ Spearman } & Temperature_effl. & 1.000 & & & & \\
\hline & pH_effl. & .297 & 1.000 & & & \\
\hline & SS_effl. & -.261 & .183 & 1.000 & & \\
\hline & COD_effl. & .124 & .235 & $.599^{* *}$ & 1,000 & \\
\hline & BOD_effl. & .026 & $.541 * *$ & $.386 *$ & $.551 * *$ & 1.000 \\
\hline \multicolumn{7}{|c|}{ **. Correlation is significant at the 0.01 level (2-tailed). } \\
\hline \multicolumn{7}{|c|}{ *. Correlation is significant at the 0.05 level (2-tailed). } \\
\hline
\end{tabular}

Studying the effluent, Pearson correlation indicate a high positive correlation amongst SS and BOD $(\mathrm{r}=0.898)$ and between SS and COD $(\mathrm{r}=0.822)$, while medium positive correlation was between $p \mathrm{H}$ and COD $(r=0.454)$ and amongst $p \mathrm{H}$ and temperature $(\mathrm{r}=0.455)$. Between COD and BOD is was also a moderate positive significant correlation between $(\mathrm{r}=0.551)$.

Analysing the effluent by Spearman's correlation it may be clearly observed strong positive significant correlation amongst SS and COD $(r=0.599)$ and $(r=0.551)$ is the correlation coefficient between COD and BOD. A weak negative correlation was amongst SS and Temperature $(\mathrm{r}=-0.261)$. It was calculated likewise a medium positive correlation amongst $p \mathrm{H}$ and BOD $(\mathrm{r}=0.541)$ in the effluent.

The general objectives of a sewage water treatment system are based on several main items: to obtain an effluent that may be discharged to a receiving water body without causing pollution, the protection of the aquatic environment from the damaging effects of wastewater discharge, and to monitor the operating efficiency taking into account the financial sustainability of water utilities.

It is obvious that, without a set of EU limits, the quality of the physical and chemical parameters of the Danube would have been different, without analysing the cumulative effect of the pollution. 


\section{Conclusions}

In the absence of modern sewage water treatment systems in the large urban agglomerations of the country, the domestic water would pollute the Danube and the Black Sea massively. It should be taken into account that the Danube river is negatively influenced by the untreated waste water spilled indirectly into the rivers in Romania. The main objective of wastewater treatment plants is to generate a waste fluid (or treated effluent) and sludge adequate for reusability in agriculture. Five physical and chemical parameters were analysed for the purpose of observing the efficiency of sewage water treatment. Both in the case of the influent and the effluent temperature has a moderate positive significant correlation with $p \mathrm{H}$, while only effluent has a good correlation with BOD. $p \mathrm{H}$ of effluent has also a moderate positive significant correlation with COD and BOD comparing with influent when it was a moderate correlation with COD. The correlation between SS and COD and BOD with was a strong positive significant in both cases of fluid analysed. The physico-chemical indicators analysed from the effluent do not exceed the limits provided by the European legislation. The results of the paper indicate the requirement to apply ordinary targets, coherent actions and programmes to betterment in the urban sewage water purifying techniques.

Acknowledgements. This work has been funded by the European Social Fund through the Sectoral Operational Programme Human Capital 2014-2020, through the Financial Agreement with the title „Burse pentru educaţia antreprenorială în rândul doctoranzilor şi cercetătorilor postdoctorat $(\mathrm{Be}$ Antreprenor!)" (in Romanian: "Scholarships for entrepreneurial education among doctoral students and postdoctoral researchers (Be Entrepreneur!)", Contract no. 51680/09.07.2019 - SMIS code: 124539.

\section{References}

1. ***Water Framework Directive, European Union (WFD E.U.). Establishing a Framework for Community Action in the Field of Water Policy; Directive 2000/60/EC of the European Parliament and of the Council of 23 October 2000; EU: Brussels, Belgium, 2000.

2. ARLE, J., MOHAUPT, V., KIRST., I., Monitoring of surface waters in Germany under the water framework directive - a review of approaches, methods and results. (2016) Water 8-217

3. FOLEY, J., DE HAAS, D., YUAN, Z.G., LANT, P., Nitrous oxide generation in fullscale biological nutrient removal wastewater treatment plants. Water Res. 44, 2010b 831-844.

4. GATERELL, M.R., GRIFFIN, P., LESTER, J.N., Evaluation of environmental burdens associated with sewage treatment processes using life cycle assessment techniques, Environ. Technol. 26, 2005231-249.

5. DIXON, A., SIMON, M., BURKITT, T., Assessing the environmental impact of two options for smallscale wastewater treatment: comparing a reed bed and an aerated biological filter using a life cycle approach. Ecol. Eng., 20, 2003, 297-308.

6. CIRTINA, D., CAPATINA, C., Quality Issues Regarding the Watercourses from Middle Basin of Jiu River, Rev. Chim., 68(1), 2017, 72-76.

7. GAUTAM, S., K., SHARMA, D., TRIPATHI, J., K., AHIRWAR, S., SINGH, S., K., A study of the effectiveness of sewage treatment plants in Delhi region, Appl. Water Sci. 3, 2013, 57-65.

8. DWIVEDI, B., K., PANDEY, G., C., Physico-chemical factors and algal diversity of two ponds in Faizabad, India Pollut. Res. 21(3), 2002, 361-370.

9.MINCU, M., MARCUS, M.I., MITIU, M.A., RAISCHI, N.S., Increasing the Efficiency of Pollutants Removal from Municipal Wastewater Using Biological Filters, Rev. Chim., 69(12), 2018, 3553-3556.

10. ITICESCU, C., GEORGESCU, L. P., TOPA, C. M., Assessing the Danube water quality index in the city of Galati, Romania, Carpathian Journal of Earth and Environmental Sciences, 2013, 8(4), 155164.

11. LIN, H.Y., HAN, W.Y., Water quality assessment and analysis before and after the decade of the dry period in Lingdingyang Estuary of the Pearl River Mouth, Mar. Environ. Sci 20 (2001) 28-31. 
12. LOKHANDE R.S., SINGARE P.U., PIMPLE S.D., Study on Physico-Chemical Parameters of Waste Water Effluents from Taloja Industrial Area of Mumbai, India International Journal of Ecosystem 2011; 1(1): 1-9 DOI: 10.5923/j.ije.20110101.01

13. HONG, A.H., LINK, L.P., SELAMAN, O.S., Determination of physicochemical quality of municipal wastewater effluent for domestic and irrigation reuse at lake geriyo irrigation sites, Yola, Northeastern Nigeria, Int. J. Environ. Sci. Manage. Eng. Res. 3(1) (2014) 8-17.

14. IGBINOSA, E.O., OKOH, A.I., Impact of discharge wastewater effluents on the physico-chemical qualities of a receiving watershed in a typical rural community, Int. J. Environ. Sci. Technol. 6(2), 2009, $175-182$.

15. KUMAR, V., CHOPRA, A.K., Monitoring of physico-chemical and microbiological characteristics of municipal wastewater at treatment plant, Haridwar City (Uttarakhand) India, J. Environ. Sci. Technol. 5(2), 2012, 109-118.

16. ZORPAS. A.A., COUMI, C., DRTIL, M., VOUKALLI, I., SAMARAS, P., Operation description and physicochemical characteristics of influent, effluent and the tertiary treatment from a sewage treatment plant of the Eastern Region of Cyprus under warm climates, Desalin. Water Treat. 22, 2010, 244-257.

17. BE'CARES, E., SOTO, F., SOTILLOS-BLAS, J.L., Wastewater characteristics and pre-treatment efficiency in small localities in north-west Spain, Desalin. Water Treat. 4, 2009, 12-15.

18. TANYOL, M., VEYSSEL, D., Correlations between some operation parameters and efficiency evaluation of domestic wastewater treatment plant in Tunceli (Turkey), 2016, Desalination and water treatment 57(58):1-7.

19. ***Council Directive 91/271/EEC of 21 May 1991 concerning urban waste-water treatment

20. WHO, Guidelines for Drinking-water Quality, fourth ed., World Health Organization, Geneva, 2011, p. 564.

Manuscript received: 20.03 .2020 